Article

\title{
Sustainable Transformative Economy: Community-Based Ecotourism
}

\author{
Marin Kim ${ }^{1}$, Yi Xie ${ }^{1, * \mathbb{D}}$ and Giuseppe T. Cirella ${ }^{2}$ (D) \\ 1 School of Economics and Management, Beijing Forestry University, No. 35, Qinghua East Road, \\ Haidian District, 100083 Beijing, China; marinkim310@yahoo.com \\ 2 Faculty of Economics, University of Gdansk, 81-824 Sopot, Poland; gt.cirella@ug.edu.pl \\ * Correspondence: yixie@bjfu.edu.cn
}

Received: 8 August 2019; Accepted: 10 September 2019; Published: 12 September 2019

check for updates

\begin{abstract}
Ecotourism has a high potential impact on remote communities, by improving economic opportunity and natural resources conservation, and is increasingly accepted as an alternative livelihood for rural people. This study examines ecotourism development from the perspective of participation and economic impact for the Bousra people in Cambodia. A total of 237 households were selected as the sample size. Data collection was carried out with face-to-face interviews and analyzed using logistic regression and ordinary least square methods. Results revealed that local households depend mostly on agriculture (i.e., crop plantation and farming) and utilize ecotourism as a secondary source of income. Most households acknowledged ecotourism had a positive impact on environmental, social, and economic perspectives, while some signaled negative backlash due to depleted natural resources and impact on local culture. Household participation in ecotourism was not significantly affected from assistance issued by government or non-governmental organizations. However, causal relationships were found based on household demographic factors, attitude to environmental conservation, and village life. It was shown that the percentage of people involvement in ecotourism is high, but their income percentage is low due to education, skill, and capacity to expand. As a low-impact alternative to standard commercial tourism, community-based ecotourism has potential in becoming a transformative form of economics for local communities.
\end{abstract}

Keywords: ecotourism; community livelihood; participation; sustainable tourism; income; Cambodia

\section{Introduction}

Ecotourism is responsible travel to a natural area that conserves the environment, sustains the well-being of local people, and integrates interpretation and education [1]. The 2002 Quebec Declaration on Ecotourism recognizes the principles of sustainable tourism by incorporating the environmental, social, and economic impacts of tourism [2]. In this study, ecotourism is specified as community-based ecotourism (CBE) and identified with rural, sustainable tourism focused on rural livelihood. Manu and Kuuder [3] state that it has been considered one of the fastest growing sectors as an alternative means of tourism to improving rural livelihood. As one of the developing countries located along the Greater Mekong River Subregion, Cambodia, along with other countries like China, Myanmar, Thailand, Laos, and Vietnam, has utilized ecotourism in poverty alleviation strategies-key to securing biodiversity conservation and solving economic disparity [3,4]. The Ministry of Planning has put together three scoping principles which form the basis for ecotourism in the country: (1) sustainability and environmental development go hand-in-hand, (2) promote its nature-based and rich cultural and historical heritage, and (3) boost tourism arrivals, expenditure, and diversity of tourist destinations via international marketing and infrastructure development [5]. Moreover, the mechanisms to develop ecotourism should expand into the private sector and encourage private investment by, directly and 
indirectly, bringing financial and technical growth to the community. Compared with conventional tourism, largely systematized by the government, ecotourism development obtained more support by non-governmental organizations (NGOs) [6]. The first ecotourism site in Cambodia was established in 1998 at Yeak Laom Lake in Ratankiri province and has become a successful, locally managed project. In 2002, the Cambodian Community-Based Ecotourism Network (CBET) was established acting as an ecotourism umbrella organization, registering as an NGO in 2005 [6,7]. Some 464,000 tourists visited CBET sites in 2007 [8]. In 2013, there were 56 ecotourism sites in various regions across Cambodia, spanning the northeast, the Tonle Sap area, along the south coast, and the southwest [6,9]. It is predicted that by 2020 , ecotourism could attract one million international and five million tourists $[9,10]$. Some ecotourism programs, such as the Chambok CBET program, have won public recognition, including in 2013 for socially responsible tourism [11] for engaging with local people to protect forests and improve local livelihood [12]. However, a recent study on Chambok reveals that there was no significant difference between the total income of villagers having ecotourism income and villagers without ecotourism income [9]. The impacts of ecotourism seem ambiguous and need further investigation.

There is a large, emerging body of literature within the discipline of ecotourism [2,4,5]. Among them, environmental impact from ecotourism is of high concern. There is also a focus on its role in enhancing environmental quality and providing an alternative to the exploitative use of environmental resources $[13,14]$, as well as serious concerns highlighting natural resource depletion, pollution (i.e., air, water, sound, and waste), soil erosion, and loss of wildlife habitat in conjunction with the risk of forest fires [15-18]. Ecotourism must also take into account visitor limitation to avoid negative environmental backlash and impact [19-21]. As such, environmental impact is interconnected with socioeconomics, having long-term detrimental effects on the economic status of local people [22]. Similarly, the benefits of infrastructure development should be properly managed (i.e., from visitor influx) to avoid environmental degradation [22-25]. Ecotourism has multiple types of socio-cultural impacts [2], including am increase in the standard of living of local residents, socio-political empowerment, and respect for cultural diversity and human rights. Indirect incentives include improved infrastructure (e.g., health facilities and schools), awareness and education from tourism development, and positive attitudes toward conservation [2,14]. Ecotourism income can also aid in uniting actors and strengthen co-existence (e.g., Cuyabeno Wildlife Reserve, a biodiversity rich area in northern Ecuador [13]). As part of the increase in extra income, investment focused on the education of children can lead to the development of human capital [26] and safe-keeping of future generations. Ecotourism has challenged traditional gender roles, and extended women's household roles of cleaning and serving others [26]. However, high numbers of tourists can cause cultural erosion, an increase in alcohol consumption, and disease risk [13].

In all, ecotourism can be seen as a double-edged sword. On the one hand, its contribution to poverty alleviation, livelihood improvement, and diversification signal a positive impact [27-31], while negative environmental impacts, the risk of inflation, and cultural degradation indicate concern [27,32]. Ferraro and Hanauer [33] found that ecotourism activity accounts for approximately two-thirds of poverty alleviation impact based on the Human Poverty Index (i.e., taken from residents' employment status, household appliances, and utility expenditure). As socioeconomic status increases the livelihood of local people taking part in ecotourism, services also become more available. However, very few studies correlate this baseline data. Much speculation, by way of observation, suggests that it does $[34,35]$. Contrary to the positive impact, ecotourism might increase the popularity of a destination, triggering inflated tourist prices for goods and services due to which local people often suffer [22,36-38]. Moreover, overpopulated tourist areas can transitionally turn from ecotourism into conventional tourism, which then varies from the eco-objectives established [39-42]. Ecotourism may also worsen income inequality in the local community, even though it may increase the income of those working within it $[9,43,44]$. As such, their still remains the challenge of employing ecotourism to achieve poverty reduction and livelihood improvement in the community [9]. 
Another controversial concern is local resident participation in ecotourism. Once local residents have a strong voice in shaping tourism development, sound community of practice (CoP) outcome can be achieved (i.e., community participation and stakeholder intervention) [22,35,36]. Ven [45] stated that local participation and CoP are key factors in ecotourism success and improved community solidarity [46]. However, local residents who have no, or limited, access to the local tourism market have a limited capacity to benefit $[3,47]$. Hence, capacity is limited to the availability of benefits for enhancing livelihood. Among successful ecotourism programs, example employment for local residents include working as a tour guide, cook, homestay host, guesthouse host, boat driver, motorcycle driver, sanitation worker, and forest patrol [6]. Among the few quantitative assessments of local resident participation in ecotourism, Kimengsi et al. [48] explored the effect of resident livelihood capital from ecotourism in the Western Highs of Cameroon. It was found that access to education and training showed an inverse relationship versus cultural festivals and wilderness and museum visits by adopting a principle component analysis in combination with the ordinary least square (OLS) technique $[48,49]$. Further findings suggest the application of structural models that consider that resident environmental knowledge can positively affect attitudes towards ecotourism, which in turn directly and indirectly determines intention to participate in the activity $[39,48,50,51]$. The robust result of factors affecting resident participation demands further quantitative studies.

The aim of this paper is to assess what factors affect local peoples' participation in ecotourism and how ecotourism contributes to their livelihood. Critical factors examine institutional factors, multiple stakeholders, and local communities who are living and working inside and around the project site by taking into consideration key questions. (1) In terms of services provided from ecotourism, what is the state of art for local communities' livelihood? (2) What are the main forms of local people participating in ecotourism? (3) What is the local people's perception of the effect of ecotourism to living within sustainable grounds? (4) How do institutional factors reflect on local people's activities in ecotourism? (5) What contribution does ecotourism play in local people's livelihood in terms of family income? A breakdown of the paper is structured as follows: Section 2 contains the methodology, Section 3 illustrates the results, Section 4 elucidates the discussion, and Section 5 concludes with recommendations for best practices.

\section{Methodology}

\subsection{Study Site}

This study was carried out in villages surrounding Bousra Waterfalls located in Picheada District, Mondulkiri province (Figure 1). Mondulkiri province is located in eastern Cambodia, is relatively remote, and most sparsely populated with large tracts of forest. The province is chock full of natural beauty, with thickly forested mountains, a large waterfall and lush green hills on its western end. In spite of this, the province suffers from the risk of deforestation caused by mining [51]. Most of the population in Mondulkiri is made up of ten tribal minorities, with the majority of them being the Chunchiet from the tribe of the Phnong. Local people lead their livelihood through traditional ways of cultivation (i.e., shifting agriculture), hunting, and collecting fruits from the forest [50]. Bousra Waterfall is the specific ecotourism-designed site and the major tourist attraction in Mondulkiri province. Ecotourism is locally defined as providing goods and services at Boursa Waterfalls as well as off-site in nearby villages. The waterfalls are 20 to $40 \mathrm{~m}$ in height and divided over three levels [51,52]. Bousra Waterfalls has been a key investment example of private sector development, namely from the private company Mayura Hill, which has taken over the management, development, and conservation of the waterfalls. The study site incorporates seven villages (i.e., Pu Til, Pu Lou, Pu Tib, Bousra, Pu Rang, Lam Mes, and Pu Cha) which surround upland forest and mountainous terrain—connected with Namlear Wildlife Sanctuary. The villages' vicinity to the ecotourism site (i.e., Bousra Waterfalls), access to local people, and willingness to partake in the research, as well as investment by the private sector made for optimum site criteria. In addition, the Cambodian government in collaboration with donors 
(i.e., private sector entities and NGOs) assisted local communities, living around the ecotourism site, to participate in developing job opportunities with the idea of ecosystem and culture conservation.

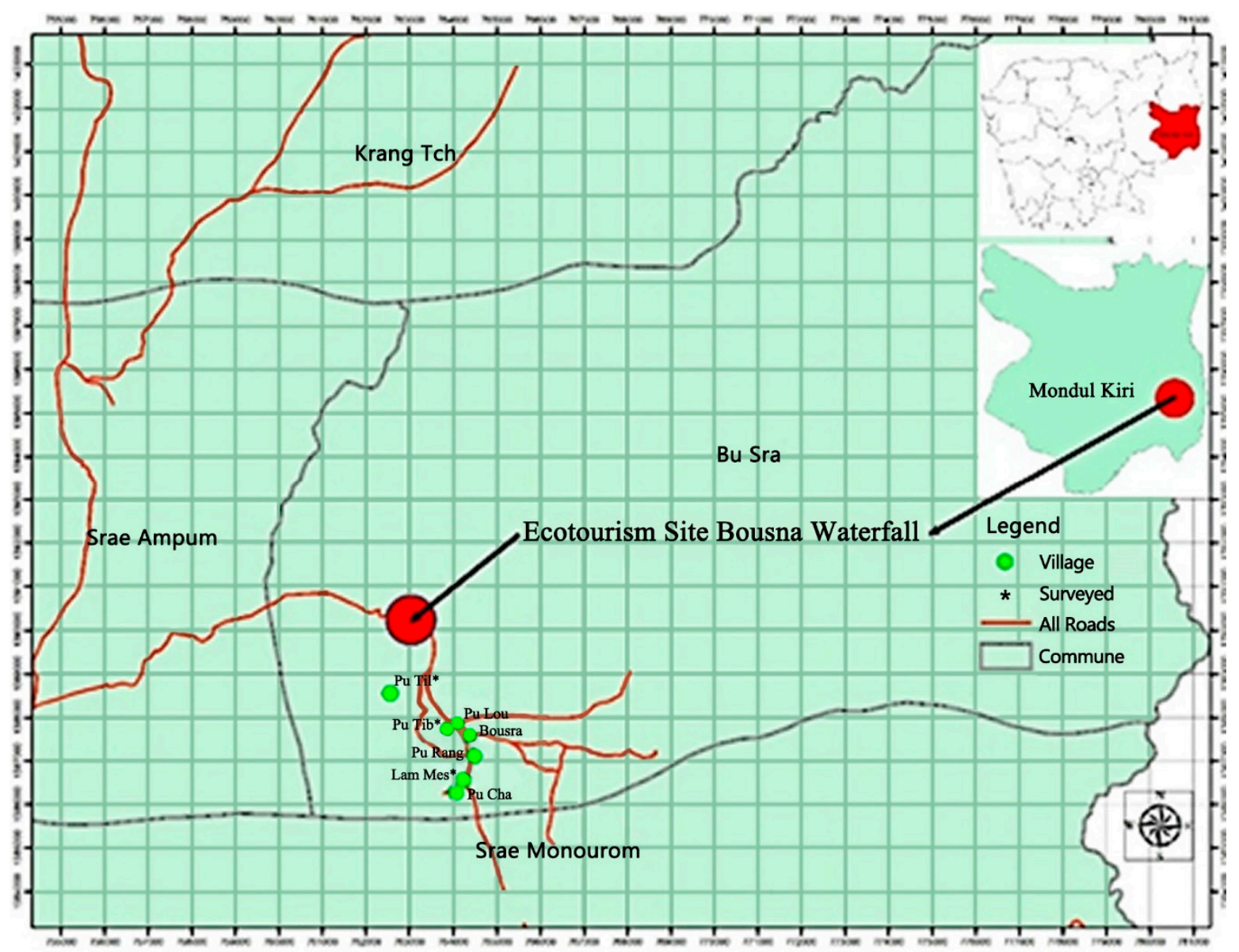

Figure 1. Map of study site.

\subsection{Data Collection}

The scope of this study examines three villages (i.e., Pu Til, Pu Tib, and Lam Mes) by adopting a stratified random sampling method, where all seven villages are stratified into three groups in terms of their distance to the ecotourism site (i.e., the nearest group was made up of only Pu Til, the medium group contained Pu Lou, Pu Tib, Bousra, and Pu Rang, and the farthest group Lam Mes and $\mathrm{PuCha}$ ), followed by one village randomly being selected from each group. The three villages were composed of 581 households, with 2714 villagers (i.e., 1539 male and 1175 female). Most of the villagers are indigenous people (i.e., Bunong — an aboriginal Cambodian minority ethnic group), who, for the most part, survive via agriculture, off-farm income, ecotourism services, and non-timber forest products (NTFPs) collection. The Bunong people also perform a number of other activities such as small home-oriented businesses, scarf weaving, sold labor, and work as civil servants. Along with the development of ecotourism, traditional agriculture still dominates local peoples' livelihood throughout the area. Over $30 \%$ of the households base their livelihood on farming such as crop cultivation and livestock breeding.

For this study, 237 respondents of the sample households were selected randomly based on a list of names provided by the Bousra Commune administration as a sample size (i.e., 95\% confidence interval with 5\% marginal error) by using the Taro Yamane Formula [38,53], Equation (1).

$$
\mathrm{n}=\frac{\mathrm{N}}{\left(1+\mathrm{Ne}^{2}\right)}
$$


where $\mathrm{n}=$ sample size, $\mathrm{N}=$ total population of household, and $\mathrm{e}=$ allowable error (i.e., $5 \%=0.05$ ).

Questionnaires were designed to collect information regarding the demographic characteristics of the household head and family members, natural resource dependence, economic situation, ecotourism-related activities, attitude to environmental conservation, and impact of ecotourism (i.e., evaluation and outcome in terms of benefit and contribution received). A pilot questionnaire was performed in the village of $\mathrm{Pu}$ Til by testing the questionnaire with 10 households. This validation process assisted in refining the questionnaire format and pretesting the data collection process. Data was collected from September to October 2018. This study used primary and secondary data to analyze the results. Primary data was obtained from face-to-face interviews of each household in target villages performed via structural questionnaires that consisted of open-ended and multiple-choice questions. The questionnaire aimed to understand key livelihood activities, sources of income, and intervention-level from institutions. Secondary data was obtained from the Provincial Department of Tourism (PDoT), Provincial Department of Environment (PDoE), and relevant NGOs. Qualitative observation methods were also employed during the sample village interviews. Four additional measurements regarding the respondents' economic situation were noted, including clothing quality, sanitary conditions, house type, and transportation value.

\subsection{Data Analysis and Method}

Data analysis was interpreted by descriptive statistics and econometrics. The descriptive statistics were applied on the sampled household livelihood, participation in ecotourism, and perception on impact of ecotourism. Binary logistic regression conducted on the activities attributed to a binary stated-choice response; the applied results investigated how respondent participation is determined. Each variable in the model was coded as one if respondents answered "yes" to an ecotourism service, zero otherwise. Following the utilization maximization theory [54], respondents made decisions based on participation in ecotourism and their perceived utilization of it-jointly affected by their demographic characteristics (i.e., age, education, family size, and labor force) as well as other characteristics relating to ecotourism (i.e., distant to ecotourism site and native residential identification) [48,54]. A reduced form of the binary logistic regression model was applied, Equation (2).

$$
\mathrm{PAR}=f(\mathrm{DEM}, \mathrm{ECO}, \mathrm{GOV}, \mathrm{NGO}, \mathrm{ATT}, \mathrm{LOC})
$$

where PAR = household participates in ecotourism and specific forms, DEM = demographic factors (i.e., age, educational level, and residential identity of household head, and labor force), $\mathrm{ECO}=$ economic condition of household (e.g., income and sufficient funds), GOV = institutional impacts (e.g., government assistance), NOG = assistance from NGOs, ATT = household attitude to environmental conservation, and LOC = village location.

OLS regression analysis was used to investigate economic impact of ecotourism for the controlled demographic characteristics (i.e., age, labor force, residential identity), economic condition, and location. The dependent variable, economic impact, was used to specify family income, which is a continuous variable (i.e., allowing for the OLS regression application). As such, a reduced calculative form of the OLS regression was used, Equation (3).

$$
\mathrm{INCOME}=f(\text { PAR, DEM, FUND, LOC })
$$

where PAR and LOC = similar definition but with different variables in comparison to the logistic model, $\mathrm{DEM}=$ same as the logistic model, and FUND = sufficient funds. 


\section{Results}

\subsection{Basic Characteristic of Households}

Our total sample reviewed 237 households from three villages with different distances to the ecotourism site of Bousra Waterfall. We initially categorized residents into two groups, of which group one consists of villagers participating in ecotourism (i.e., denoted as IN) and group two for villagers not participating in ecotourism (i.e., denoted as NOT). For those households participating in ecotourism (i.e., group one), further subcategorization was denoted for residents who only participated in ecotourism (i.e., denoted as ONLY) and for those who participated both in ecotourism and conventional tourism (i.e., denoted as BOTH). We then had 151 households in ecotourism and 86 households not in ecotourism, 32 households only in ecotourism and 119 household both in ecotourism and conventional tourism. Household characteristics showed that the age of the household head was approximated 39 years old, with slight differences among different groups. Nearly all household heads were male. The education levels of the household heads indicated only primary school levels were achieved, with mean levels ranging from the fourth to fifth grade. Most households are native and have lived in their villages for over 20 years. The results of the "IN" and "BOTH" groups indicate that native villagers have a higher participation rate both in ecotourism and conventional tourism.

The labor force of each household was the main factor that advanced the economics of the household-varying from two to five members, with a total mean value of 2.99. It was evident that some families did not have enough labor force to work their own agricultural land and thus earn enough money for livelihood enhancement. With limited education, their livelihood activities were weighed towards sold labor and survival skills as a basis for knowledge procurement. As a result, there was a correlative problem that isolated some of households from participating in social activities. Households mostly did not have good economic performance (i.e., average annual income per household equated to US\$ 3510). Considering the average family size was six, the income per capita corresponded to US\$ 2 per day. Over 70\% of households faced insufficient funds for production activities. For the "ONLY" group, over $90 \%$ of households lacked sufficient funds.

Policy assistance from the government (i.e., PDoT and PDoE) had similar influential ratios with exception to a relatively low ratio reported by the "ONLY" group in regards to assistance from the PDoE. Compared to policy assistance from the government, assistance from NGOs resulted in a much higher influence. For all groups, over $80 \%$ of households received, at least once, assistance from NGOs.

Our sample was evenly distributed among the three villages. The distance from either of the three villages to the ecotourism site was seen as not a problem since the furthest is located only $7 \mathrm{~km}$ away. Problems were found with access and travel condition due to poor road conditions, especially during and after rain due to slippery, muddy roads and paths. The availability of food is also a concern as some respondents replied not having enough food-annually. A key issue was the availability of agricultural land used for planting crops other than rice; as such, farmers continue to believe yields from other crops are better and more economically advantageous than rice yields (Table 1). 
Table 1. Household socioeconomic characteristics in the target villages ${ }^{\dagger}$.

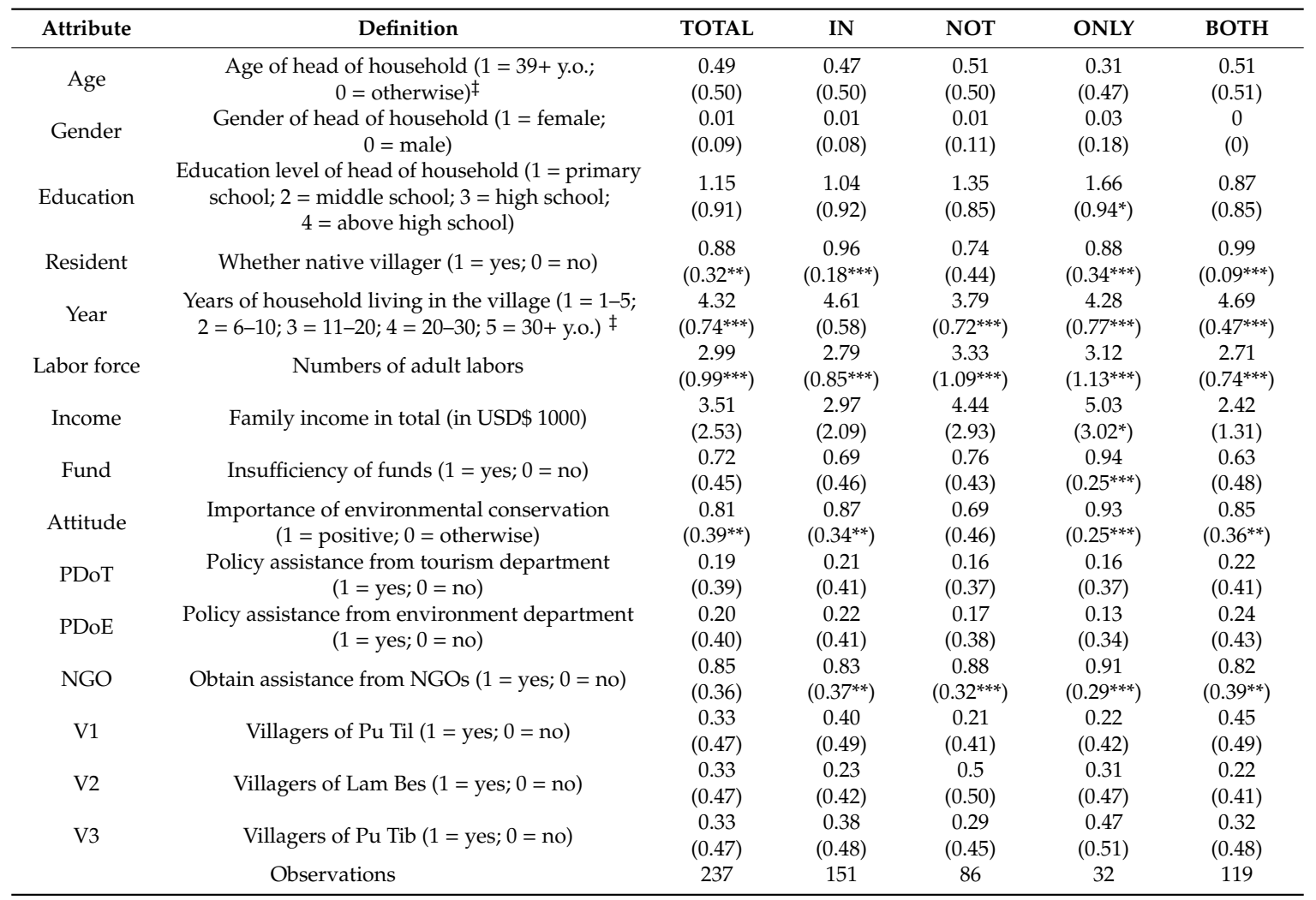

${ }^{\dagger}$ Standard errors in parentheses. ${ }^{* * *} p<0.01,{ }^{* *} p<0.05,{ }^{*} p<0.10 ;{ }^{\ddagger}$ y.o. $=$ years old; PDoT $=$ Provincial Department of Tourism; PDoE = Provincial Department of Environment; NGO = non-governmental organization.

In the three sampled villages, it was found that the livelihood activities of the locals were primarily agriculture, followed by eco-based services, home businesses, livestock raising, government employment, and other miscellaneous sources. Most of them had residence in Bousra Commune, while all of them had access to their own personal piece of property (i.e., with land titling at the commune level). Land for housing, agriculture activities, and gardening were considered as land ownership by local people. Farming (i.e., mainly paddy rice cultivation) is the major source of livelihood in Cambodia but in this study, economic crop cultivation (i.e., cassava, pepper, coffee plantation, and cashew) was the major source. Besides farming (i.e., $36 \%$ ), ecotourism activities made up the second source of income at $21 \%$. As such, each household depended on different livelihood activities such as other miscellaneous sources (i.e., sold labor such as carpenter and other private sector jobs), home businesses, civil servant, and livestock-19\%, 13\%, 9\%, and 2\%, respectively.

\subsection{Perception and Forms of Participation in Ecotourism}

\subsubsection{Perception of Ecotourism by Villagers}

The concept of local people involved in fostering ecotourism has been modestly studied in developing CBE. Table 2 reports on the environmental, social, and economic impacts of ecotourism based on respondents' perception [2,46,48]. Results indicate the potential of ecotourism had both positive and negative impacts on local communities. It illustrates that ecotourism has brought the local community an increased level of opportunity (i.e., 95\%), directly giving them access to earn extra income and increase market choice for their products. As such, besides selling at the local market, they can also sell to middlemen at the ecotourism site or they themselves (i.e., $97 \%$ ). However, among respondents, approximately $80 \%$ stated it could be possible to improve the local infrastructure solely via ecotourism-means. For the "ONLY" group, there was significantly higher (i.e., almost unanimous) 
agreement on the positive impact of ecotourism on infrastructure level. Important factors include government (i.e., institutional factors) and community-run programs directly from villagers as other viable systems for development (Table 2).

Table 2. Perception from the impact of ecotourism ${ }^{\dagger}$.

\begin{tabular}{|c|c|c|c|c|c|c|}
\hline$C^{\ddagger}$ & Subcategory & Total & IN & NOT & ONLY & ВОТН \\
\hline \multirow{4}{*}{$\begin{array}{l}\text { Environmental } \\
\text { impact }\end{array}$} & $\begin{array}{c}\text { Awareness of natural resources } \\
\text { conservation }(1=\text { yes } \\
0=\text { otherwise })\end{array}$ & $\begin{array}{c}0.79 \\
\left(0.41^{* *}\right)\end{array}$ & $\begin{array}{c}0.85 \\
\left(0.36^{* *}\right)\end{array}$ & $\begin{array}{c}0.69 \\
(0.46)\end{array}$ & $\begin{array}{c}0.84 \\
\left(0.37^{* *}\right)\end{array}$ & $\begin{array}{c}0.85 \\
\left(0.36^{* *}\right)\end{array}$ \\
\hline & $\begin{array}{l}\text { Increased waste management } \\
\text { ( } 1=\text { yes, } 0=\text { otherwise })\end{array}$ & $\begin{array}{c}0.74 \\
(0.44)\end{array}$ & $\begin{array}{c}0.74 \\
(0.44)\end{array}$ & $\begin{array}{c}0.76 \\
(0.43)\end{array}$ & $\begin{array}{c}0.88 \\
\left(0.34^{* * *}\right)\end{array}$ & $\begin{array}{c}0.69 \\
(0.46)\end{array}$ \\
\hline & Depleted local environment & 0.34 & 0.26 & 0.48 & 0.06 & 0.32 \\
\hline & (1 = yes, $0=$ otherwise $)$ & $(0.48)$ & $(0.44)$ & $(0.50)$ & $\left(0.34^{* * *}\right)$ & $(0.47)$ \\
\hline \multirow{4}{*}{ Social impact } & Increased immigration ( 1 = yes, & 0.94 & 0.91 & 1 & 1 & 0.88 \\
\hline & $0=$ otherwise) & $\left(0.24^{* * *}\right)$ & $\left(0.29^{* * *}\right)$ & (0) & (0) & $\left(0.32^{* * *}\right)$ \\
\hline & Impacted local culture $(1=$ yes, & 0.13 & 0.15 & 0.10 & 0.06 & 0.17 \\
\hline & $0=$ otherwise) & $(0.34)$ & $(0.35)$ & $(0.31)$ & $(0.25)$ & $(0.38)$ \\
\hline \multirow{6}{*}{$\begin{array}{l}\text { Economic } \\
\text { impact }\end{array}$} & Extra income opportunity & 0.95 & 0.95 & 0.95 & 0.88 & 0.97 \\
\hline & $(1=$ yes, $0=$ otherwise $)$ & $\left(0.21^{* * *}\right)$ & $\left(0.21^{* * *}\right)$ & $\left(0.21^{* * *}\right)$ & $\left(0.34^{* * *}\right)$ & $\left(0.16^{* * *}\right)$ \\
\hline & Increased market of products & 0.97 & 0.99 & 0.93 & 0.99 & 1 \\
\hline & $(1=$ yes, $0=$ otherwise $)$ & $\left(0.17^{* * *}\right)$ & $(0.08)$ & $\left(0.26^{* * *}\right)$ & $\left(0.18^{* * *}\right)$ & (0) \\
\hline & Improved infrastructure & 0.78 & 0.78 & 0.83 & 0.94 & 0.74 \\
\hline & $(1=$ yes, $0=$ otherwise $)$ & $\left(0.40^{* *}\right)$ & $\left(0.41^{* *}\right)$ & $\left(0.38^{* *}\right)$ & $\left(0.25^{* * *}\right)$ & $(0.44)$ \\
\hline & Observations & 237 & 151 & 86 & 32 & 119 \\
\hline
\end{tabular}

Ecotourism promotes a clean environment and natural resource protection to the host community [40]. Local communities responded by stating the awareness of natural resources conservation and increased waste management bettered in both the ecotourism site and their communities via ecotourism investors and educative dissemination from local authorities. However, some respondents noted ecotourism caused degradation and depletion to the environment due to road development, traffic, the clearing of forest for parking, and augmentation of visitors, which led to increased waste in both the ecotourism site and their community. The majority of households (i.e., $94 \%$ ) agreed that the overall population of people living and working in Bousra Commune was too high, while some stated it had just started to develop-making it an easy place to live, work, and earn an income (i.e., in contrast to more crowded provinces). Consequently, ecotourism was not the sole reason for the increase in local population. Moreover, some visitors (i.e., tourists) visit the community to experience indigenous life and traditional people. Village tourists who stay within the host community bring direct income for the host family and local village.

\subsubsection{Forms of Participation in Ecotourism}

Results indicate that household participation in ecotourism occurred via multiple activities associated with the ecotourism site (i.e., Bousra Waterfalls). The selling of NTFPs was the most active selling option (i.e., accounting for 75\% of households from the 'IN' group), followed by sales of souvenirs $(15 \%)$, fruit and soft drinks $(9.9 \%)$, food $(7 \%)$, camp facility rentals $(4 \%)$ and photograph services (3\%). It was surprising that less than $1 \%$ of respondents said they had been working as a service supplier (i.e., ecotourism site staff) in Bousra Waterfalls.

Even though, in theory, ecotourism should provide job opportunities to local communities, the number of household heads had a very low level of formal education, translating so-called capacity to obtain higher-end employment within the ecotourism site as limiting - requiring expertise from outside the community. Regardless, the participation of the local people within a CBE framing still offered a wide array of selling opportunity, free for indigenous groups to expand, and niche market-driven. 


\subsection{Factors Affecting Participation in Ecotourism}

Factors affecting participation in ecotourism utilized logistic regression modeling to identify linkages between dependent and independent variables, wherein assessed independent factors were considered not significant (i.e., at the $90 \%, 95 \%$, and 99\% significance level). We reported results for six models, of which the first set of three applied results from all the sample villagers and the latter set applied results from only the sample villagers participating in tourism, in general (Table 3). Models were tested to examine the robustness and impact of ecotourism and tourism, in general, on the communities. Both sets of models utilized the same variables and related significance levels.

Table 3. Logistic regression results of variables attributed to participation in ecotourism ${ }^{\dagger}$.

\begin{tabular}{|c|c|c|c|c|c|c|}
\hline \multirow[b]{2}{*}{ Variable } & \multicolumn{3}{|c|}{ Set 1} & \multicolumn{3}{|c|}{ Set 2} \\
\hline & Total/1 & Total/2 & Total/3 & IN/1 & IN/2 & IN/3 \\
\hline Gender & $\begin{array}{l}-0.46 \\
(1.55)\end{array}$ & $\begin{array}{l}-0.43 \\
(1.50)\end{array}$ & $\begin{array}{l}-0.44 \\
(1.53)\end{array}$ & & & \\
\hline Education & $\begin{array}{c}0.11 \\
(0.40)\end{array}$ & $\begin{array}{c}0.17 \\
(0.43)\end{array}$ & $\begin{array}{c}0.11 \\
(0.40)\end{array}$ & $\begin{array}{l}-0.94 \\
\left(0.51^{*}\right)\end{array}$ & $\begin{array}{c}-1.01 \\
\left(0.51^{* *}\right)\end{array}$ & $\begin{array}{l}-0.89 \\
\left(0.51^{*}\right)\end{array}$ \\
\hline Resident & $\begin{array}{c}0.98 \\
\left(0.17^{* * *}\right)\end{array}$ & $\begin{array}{c}0.97 \\
\left(0.17^{* * *}\right)\end{array}$ & $\begin{array}{c}0.98 \\
\left(0.17^{* * *}\right)\end{array}$ & $\begin{array}{c}-0.72 \\
\left(0.29^{* *}\right)\end{array}$ & $\begin{array}{c}-0.66 \\
\left(0.28^{* *}\right)\end{array}$ & $\begin{array}{c}-0.74 \\
\left(0.28^{* * *}\right)\end{array}$ \\
\hline Labor force & $\begin{array}{l}-0.33 \\
\left(0.18^{*}\right)\end{array}$ & $\begin{array}{l}-0.34 \\
\left(0.18^{*}\right)\end{array}$ & $\begin{array}{l}-0.33 \\
\left(0.18^{*}\right)\end{array}$ & $\begin{array}{c}0.15 \\
(0.28)\end{array}$ & $\begin{array}{c}0.16 \\
(0.27)\end{array}$ & $\begin{array}{c}0.15 \\
(0.28)\end{array}$ \\
\hline Fund & $\begin{array}{l}-0.79 \\
\left(0.44^{*}\right)\end{array}$ & $\begin{array}{c}-0.83 \\
\left(0.44^{*}\right)\end{array}$ & $\begin{array}{c}-0.79 \\
\left(0.44^{*}\right)\end{array}$ & $\begin{array}{c}2.31 \\
\left(0.94^{* *}\right)\end{array}$ & $\begin{array}{c}2.27 \\
\left(0.90^{* *}\right)\end{array}$ & $\begin{array}{c}2.35 \\
\left(0.93^{* *}\right)\end{array}$ \\
\hline Attitude & $\begin{array}{c}1.49 \\
\left(0.46^{* * *}\right)\end{array}$ & $\begin{array}{c}1.52 \\
\left(0.47^{* * *}\right)\end{array}$ & $\begin{array}{c}1.49 \\
\left(0.46^{* * *}\right)\end{array}$ & $\begin{array}{c}0.87 \\
(0.85)\end{array}$ & $\begin{array}{c}0.78 \\
(0.84)\end{array}$ & $\begin{array}{c}0.89 \\
(0.85)\end{array}$ \\
\hline PDoT & $\begin{array}{c}0.45 \\
(0.47)\end{array}$ & & $\begin{array}{c}0.45 \\
(0.47)\end{array}$ & $\begin{array}{l}-0.67 \\
(0.63)\end{array}$ & & $\begin{array}{l}-0.68 \\
(0.62)\end{array}$ \\
\hline PDoE & $\begin{array}{c}0.39 \\
(0.44)\end{array}$ & & $\begin{array}{c}0.36 \\
(0.44)\end{array}$ & $\begin{array}{l}-0.69 \\
(0.51)\end{array}$ & & $\begin{array}{l}-0.78 \\
(0.65)\end{array}$ \\
\hline NGO & $\begin{array}{l}-0.06 \\
(0.53)\end{array}$ & $\begin{array}{l}-0.06 \\
(0.52)\end{array}$ & & $\begin{array}{c}0.51 \\
(0.73)\end{array}$ & $\begin{array}{c}0.67 \\
(0.72)\end{array}$ & \\
\hline $\mathrm{V} 1$ & $\begin{array}{l}-0.95 \\
\left(0.52^{*}\right)\end{array}$ & $\begin{array}{c}-0.97 \\
\left(0.52^{*}\right)\end{array}$ & $\begin{array}{l}-0.96 \\
\left(0.52^{*}\right)\end{array}$ & $\begin{array}{l}-0.78 \\
(0.59)\end{array}$ & $\begin{array}{l}-0.74 \\
(0.59)\end{array}$ & $\begin{array}{l}-0.74 \\
(0.59)\end{array}$ \\
\hline V2 & $\begin{array}{c}-1.76 \\
\left(0.51^{* * *}\right)\end{array}$ & $\begin{array}{c}-1.72 \\
\left(0.51^{* * *}\right)\end{array}$ & $\begin{array}{c}-1.75 \\
\left(0.51^{* * *}\right)\end{array}$ & $\begin{array}{c}0.21 \\
(0.57)\end{array}$ & $\begin{array}{c}0.26 \\
(0.57)\end{array}$ & $\begin{array}{c}0.26 \\
(0.57)\end{array}$ \\
\hline Constant & $\begin{array}{l}-2.12 \\
\left(1.09^{*}\right)\end{array}$ & $\begin{array}{l}-1.91 \\
\left(1.07^{*}\right)\end{array}$ & $\begin{array}{c}-2.17 \\
\left(1.09^{* *}\right)\end{array}$ & $\begin{array}{l}-0.66 \\
(1.97)\end{array}$ & $\begin{array}{l}-1.18 \\
(1.91)\end{array}$ & $\begin{array}{l}-0.22 \\
(1.87)\end{array}$ \\
\hline Observation & 237 & 237 & 237 & 151 & 151 & 151 \\
\hline
\end{tabular}

Results from all of the models indicate that policy assistance obtained by local residents from the PDoT and PDoE did not have a significant impact on their participation level in ecotourism-similar assistance findings from NGOs were observed. The education levels of household heads did not have a significant impact on household participation in ecotourism. However, for those households participating in tourism in general, the more education received, the more likely that both ecotourism and conventional tourism was employed. The length of household living, in the village as a native resident, was positively correlated to ecotourism activities (i.e., native residents resided in the village longer and had a larger probability of participating in ecotourism). However, for those residents in tourism in general, the longer residing residents had a smaller probability of participating only in ecotourism. Family labor size was negatively correlated with ecotourism access-the more family labor, the less likely it was involved with the ecotourism site or earned money via ecotourism.

Insufficient funds have adverse impacts on household participation in ecotourism when considering the total sample and the "IN" sample. For the total sample, insufficient funds made households less likely to be involved in ecotourism, whereas for the "IN" sample, insufficient funds made households only more likely to be involved in ecotourism and not tourism in general. Household attitude to environmental conservation had a positive and significant impact on their participation in ecotourism. When households recognized the importance of environmental conservation, there 
was a larger chance they would be involved in ecotourism. However, household attitude did not have a significant impact on participation when focused on the "IN" sample. Distance is negatively correlated with ecotourism access. The nearest target village (i.e., Pu Til) located in the forest faces travel concerns due to its vicinity (i.e., off the main road) and road condition (i.e., poor and muddy). In contrast, the medium and furthest villages (i.e., Pu Tib and Lam Mes) have direct access to the main road, which is very well built and easily accessible via vehicle services. Furthermore, qualitative observation indicates that the nearest village was significantly underdeveloped in comparison to the other two villages as well as villagers giving the impression as being more isolated, conservative, and less approachable to speak to and less likely to go out to earn money, especially women.

\subsection{Factors Affecting the Economic Impact of Ecotourism}

We employed OLS estimate factors affecting the economic impact of ecotourism. To avoid the subjectivity of household perception on economic perception (Table 2), we applied household income to indicate economic impact. We report the result of five models, of which the first three models (i.e., set 1) apply to all sample villagers and the latter two models (i.e., set 2 ) only apply to sample villagers participating in tourism. These models were applied to capture the detailed economic impact of ecotourism (Table 4).

Table 4. Ordinary least square (OLS) regression of variable-to-income results of local residents.

\begin{tabular}{|c|c|c|c|c|c|}
\hline \multirow[b]{2}{*}{ Variable } & \multicolumn{3}{|c|}{ Set 1} & \multicolumn{2}{|c|}{ Set 2} \\
\hline & Total/1 & Total/2 & Total $+/ 3$ & IN/1 & IN/2 \\
\hline Gender & $\begin{array}{c}0.96 \\
\left(0.35^{* * *}\right)\end{array}$ & $\begin{array}{c}0.91 \\
\left(0.35^{* *}\right)\end{array}$ & $\begin{array}{c}1.02 \\
\left(0.34^{* * *}\right)\end{array}$ & $\begin{array}{c}1.03 \\
\left(0.43^{* *}\right)\end{array}$ & $\begin{array}{c}1.46 \\
\left(0.40^{* * *}\right)\end{array}$ \\
\hline Education & $\begin{array}{c}-0.55 \\
\left(0.08^{* * *}\right)\end{array}$ & $\begin{array}{c}-0.55 \\
\left(0.08^{* * *}\right)\end{array}$ & $\begin{array}{c}-0.51 \\
\left(0.08^{* * *}\right)\end{array}$ & $\begin{array}{c}-0.53 \\
\left(0.09^{* * *}\right)\end{array}$ & $\begin{array}{c}-0.41 \\
\left(0.09^{* * *}\right)\end{array}$ \\
\hline Resident & $\begin{array}{c}-0.18 \\
\left(0.03^{* * *}\right)\end{array}$ & $\begin{array}{c}-0.18 \\
\left(0.03^{* * *}\right)\end{array}$ & $\begin{array}{c}-0.18 \\
\left(0.02^{* * *}\right)\end{array}$ & $\begin{array}{c}-0.15 \\
\left(0.04^{* * *}\right)\end{array}$ & $\begin{array}{c}-0.14 \\
\left(0.04^{* * *}\right)\end{array}$ \\
\hline Labor & $\begin{array}{l}-0.06 \\
\left(0.03^{*}\right)\end{array}$ & $\begin{array}{l}-0.07 \\
\left(0.03^{*}\right)\end{array}$ & $\begin{array}{c}-0.08 \\
\left(0.03^{* *}\right)\end{array}$ & $\begin{array}{l}-0.06 \\
(0.04)\end{array}$ & $\begin{array}{c}-0.08 \\
\left(0.04^{* *}\right)\end{array}$ \\
\hline Fund & $\begin{array}{c}0.14 \\
\left(0.07^{* *}\right)\end{array}$ & $\begin{array}{c}0.12 \\
\left(0.07^{* *}\right)\end{array}$ & $\begin{array}{c}0.11 \\
(0.07)\end{array}$ & $\begin{array}{c}0.09 \\
(0.07)\end{array}$ & $\begin{array}{c}0.06 \\
(0.09)\end{array}$ \\
\hline IN & $\begin{array}{c}0.02 \\
(0.08)\end{array}$ & & & & \\
\hline ONLY & & $\begin{array}{c}0.15 \\
(0.09)\end{array}$ & & $\begin{array}{c}0.19 \\
\left(0.09^{* *}\right)\end{array}$ & \\
\hline $\begin{array}{l}\text { Ecotourism } \\
\text { Food }\end{array}$ & & & $\begin{array}{c}0.28 \\
\left(0.15^{*}\right)\end{array}$ & & $\begin{array}{c}0.44 \\
\left(0.16^{* * *}\right)\end{array}$ \\
\hline Ecotourism & & & 0.08 & & $\begin{array}{c}0.19 \\
(0.13)\end{array}$ \\
\hline Drinks & & & $(0.15)$ & & $(0.13)$ \\
\hline Ecotourism & & & 0.01 & & $\begin{array}{l}-0.02 \\
(016)\end{array}$ \\
\hline Souvenirs & & & (0.12) & & $(0.16)$ \\
\hline $\begin{array}{l}\text { Ecotourism } \\
\text { Camping } \\
\text { Rental }\end{array}$ & & & $\begin{array}{c}0.58 \\
\left(0.19^{* * *}\right)\end{array}$ & & $\begin{array}{c}0.63 \\
\left(0.17^{* * *}\right)\end{array}$ \\
\hline Ecotourism & & & 0.64 & & 0.78 \\
\hline Photography & & & $\left(0.23^{* * *}\right)$ & & $\left(0.19^{* * *}\right)$ \\
\hline $\begin{array}{l}\text { Ecotourism } \\
\text { Tour }\end{array}$ & & & $\begin{array}{c}0.39 \\
(0.28)\end{array}$ & & $\begin{array}{c}0.31 \\
(0.23)\end{array}$ \\
\hline $\begin{array}{l}\text { Ecotourism } \\
\text { NTFP }\end{array}$ & & & $\begin{array}{l}-0.06 \\
(0.08)\end{array}$ & & $\begin{array}{c}0.05 \\
(0.13)\end{array}$ \\
\hline V1 & $\begin{array}{c}0.04 \\
(0.09)\end{array}$ & $\begin{array}{c}0.05 \\
(0.09)\end{array}$ & $\begin{array}{c}0.06 \\
(0.09)\end{array}$ & $\begin{array}{c}0.17 \\
\left(0.09^{*}\right)\end{array}$ & $\begin{array}{c}0.11 \\
(0.09)\end{array}$ \\
\hline V2 & $\begin{array}{c}0.28 \\
\left(0.09^{* * *}\right)\end{array}$ & $\begin{array}{c}0.28 \\
\left(0.09^{* * *}\right)\end{array}$ & $\begin{array}{c}0.23 \\
\left(0.09^{* *}\right)\end{array}$ & $\begin{array}{c}0.48 \\
\left(0.09^{* * *}\right)\end{array}$ & $\begin{array}{c}0.41 \\
\left(0.10^{* * *}\right)\end{array}$ \\
\hline Constant & $\begin{array}{c}2.36 \\
\left(0.15^{* * *}\right)\end{array}$ & $\begin{array}{c}2.37 \\
\left(0.15^{* * *}\right)\end{array}$ & $\begin{array}{c}2.41 \\
\left(0.15^{* * *}\right)\end{array}$ & $\begin{array}{c}2.16 \\
\left(0.24^{* * *}\right)\end{array}$ & $\begin{array}{c}2.03 \\
\left(0.25^{* * *}\right)\end{array}$ \\
\hline Observation & 237 & 237 & 237 & 151 & 151 \\
\hline
\end{tabular}

${ }^{\dagger}$ Standard errors in parentheses. ${ }^{* * *} p<0.01,{ }^{* *} p<0.05,{ }^{*} p<0.10$. 
For the total sample models, results indicate that neither households in ecotourism or "ONLY" in ecotourism have a significant impact on family income. For the "IN" sample, results indicate that if households were "ONLY" in ecotourism, they will have a higher income. When considering the detailed impacts of each form of participation in ecotourism, we found that for both the total sample model and "IN" sample model, participation in selling food and renting camping facilities had significant and positive economic impact. The larger the activity, the higher the family income. Gender of household head had positive impact on family income in all five models, which correlated to if families had a female household head, family income tended to be higher. Moreover, the education levels of the household head had significant and negative impacts on family income in all models (i.e., due to very low levels). Length of the households living in the village as a native resident was negatively correlated with family income, which meant aged native householders earn lower income levels. The family labor force had a significant and negative impact in four models. Counterintuitively, the more labor force a household had, the smaller income levels they might have. In two total sample models, insufficient funds corresponded to higher income. Results also indicated that households from the village Lam Wes were likely to have a higher income than villagers from the other two when controlling for other variables. However, in one "IN" sample model, households from village Pu Til were likely to have higher income, respectively.

\section{Discussion}

This study aimed at examining the development of ecotourism from the perspectives of local participation, perception, and economic impact. As expected, ecotourism is one of the alternative sustainable income sources that the local community shares-directly and indirectly via the ecotourism site. As such, the study showed that ecotourism helped to protect local natural resources, the environment, and develop socioeconomic enhancement; most of the households thought that the ecotourism sector had a positive impact on household status and the community at large [45]. This study also suggests that household livelihood strategies are diversified, and most livelihood-oriented activities have benefitted, including agriculture activities, raising of animals, off-farm activities, employment, forest product collection, and home businesses. The study from Heinen and Shrestha-Acharya [41] and Das [42] found that villagers living in forested areas depend on NTFP collection and agriculture as their main source of income. Similarly, we concurred in this study that the majority of Bousra Commune practice agricultural activities (i.e., farming) and livestock ranging.

At present, there is a growing market, eight months of the year (i.e., from November to June), of popular tourist destinations throughout Cambodia for national and international visitors. In 2018, Mondulkiri province attracted 66,352 visitors, of which 8507 were foreigners [55]. It was observed that a growing number of visitors are opting to spend their holidays and leisure time in nature, so it can be assumed that the potential industry to develop ecotourism throughout Mondulkiri province and Cambodia is high. We have established that ecotourism can increase the market for local products, improve the local environment (i.e., especially waste management and nature protection), and develop infrastructure. Recently, the Cambodian government's new ecotourism policy put in place the mechanism that encourages private investors and local communities to gain capacity and ability to control ecotourism sites and invest in the sector [55]. Hence, we found that government assistance plays an important role in further developing the whole of the industry by offering individual households incentives and opportunities to participate without obligation. Activities such as selling souvenirs, fruit and soft drinks, food, NTFPs, camp facility rentals, photograph services, and jobs relating to security are among some of the current mechanisms being pushed forward. Among these activities, selling NTFPs (i.e., wild fruit, vegetables, traditional medicinal plants, rock, and honey) makes up $49 \%$ of the share. In Bousra Commune, a growing number of villagers depend on ecotourism as it continues to grow and make up a higher percentage of households' direct and indirect income. However, direct access to the ecotourism site showed that revenue shares from ecotourism activities are still somewhat limited in terms of replacing agriculture as a form of subsistence. 
Ecotourism was regarded as an additional source of income for local households. It not only provided the opportunity to earn extra income, but also conserved nature and environmental enhancement in conjunction with bettering livelihood status [21,56-58]. Our results indicate that ecotourism activities are complementary to other livelihood activities. For those households with more labor force, they were less likely to participate in ecotourism, implying ecotourism is not a labor heavy activity and requires less family members. This deduction is supported by our observation in the field, where over $50 \%$ of the local people engaged in major ecotourism activities such as NTFPs and food sales were older-aged people and children (i.e., who we did not include as a part of the adult labor force). The negative impact of insufficient funds on participation implied that local villagers are less likely to participate in ecotourism when faced with this issue, and ecotourism activities, for the most part, cannot be performed without some sufficient startup funds. However, for those already in ecotourism, when funds were insufficient, they were also more likely to participate in conventional tourism.

There are some obstacles for local people to fully benefit from ecotourism's goods and service. Household participation in ecotourism does not ensure that they will have a higher income. This implies that the profitability of ecotourism is not a guaranteed formula for success. Furthermore, comparing incomes from households within ecotourism and those not within indicates that ecotourism was less profitable. However, those villagers only in ecotourism had the highest income. At present, throughout Bousra Commune, community involvement in ecotourism is not yet significantly developed, since most provide only NTFPs which are not very lucrative. Other services, however, such as food sales, renting camping facilities, and photography services are fully feasible in generating higher income levels. Regarding the low participation of these three activities, it can be inferred that since these activities were provided by fewer villagers, there may be an untapped niche market. As noted, the impact of labor force on income was a counterintuitive finding. One possible reason is that most ecotourism activities are by in large not labor intensive (i.e., such as in farming or construction) and household family size may be an important factor on whether participating in ecotourism is profitable. It can be inferred that a smaller family nucleus (i.e., less labor force) working in agriculture, for example, might veer towards ecotourism activities to offset insufficient funds. The impact of insufficient funds also noted, somewhat paradoxically, that results for households with higher economic status demanded higher levels of income and reported higher levels of insufficient funds than lower strata households.

Poverty alleviation is one of the main goals of establishing ecotourism throughout Cambodia [33,51]. Livelihood enhancement and nature resource awareness are the conditions needed to reach poverty alleviation through livelihood activities, jobs opportunities, and solidarity via society. The balance between natural resource management, economic development, and benefit sharing are other important factors when considering the participation of stakeholders and the community as a whole [18]. With the potential of developing ecotourism in Bousra Commune, we need to consider the activity (i.e., mechanism-oriented) and pay special attention to any sudden increase in population (i.e., migration) into the community. Upholding community safety, identity, and cultural conservation as indigenous people are important dynamics local authorities, NGOs, and relevant institutions need to closely attend to when considering gaps in the economy.

\section{Conclusions}

There is a high percentage of rural participants engaged in ecotourism on- and off-site in Bousra Waterfalls. As such, the local village economy is still dominated by traditional agriculture in which ecotourism income accounts for only a small percentage of family income. This implies potential and merit evaluation. At the moment, there are multiple participatory forms of ecotourism which are not economically viable on a mass village-scale level. Most local people positively evaluate the impact of ecotourism on their livelihood, while a few stated negative impacts on depleted natural resources and culture loss. Local peoples' participation in ecotourism tends to be autonomous without significant impact or assistance from government departments or NGOs. From our perspective, ecotourism plays a conditional role on local peoples' livelihood. Notedly, our results are highly-correlated to the local 
villagers and the economic impact of ecotourism in relation to the ecotourism site selected; therefore, the citation of our findings when interpreting other cases needs to be cautious.

We propose three recommendations as vital sustainability-oriented factors in developing ecotourism in Bousra Commune. (1) Since, ecotourism provides extra income to local people in the form of direct and indirect access, local people who go into ecotourism (i.e., mostly selling NTFPs) should be provided with vocational training and skills to produce NTFPs that are not solely raw material based [59,60]. (2) Exploring the option of niche market opportunities, villagers should be encouraged to place value on additional forms of wealth creation via ecotourism. The collaboration of investors and the community at large can be initiated with formal group discussions to develop a community-based organization to establish participatory decision making for any activity including development, services, and management $[8,51]$. (3) Though ecotourism is market-oriented in practice, a governmental monitoring system is still needed to establish and avoid potential negative impacts on the environment and culture. Education for local villagers is needed as well, especially for those who rely highly on natural resources for income extraction, since ecotourism also depends on a sound environment for tourists [61]. As an intended low-impact and small-scale alternative to standard commercial tourism, CBE can be a transformative form of economics, directly benefiting the economic development and political empowerment of local communities. Considering a lack of quantitative analyses on the development of ecotourism, we suggest further comparative research between ecotourism and conventional tourism within the same region to measure the economic and institutional factors and long-term dynamics of the various ecotourism activities. Further comparative research with similar ecotourism sites in the region would also be recommended.

Author Contributions: Conceptualization, validation, formal analysis, writing-original draft preparation: M.K. and Y.X.; Investigation: M.K.; Methodology, resources, writing-review and editing: M.K., Y.X., and G.T.C.; Supervision: Y.X.

Funding: This research is supported by the Fundamental Research Funds from Central University under Grant No.: 2018BLRD001.

Acknowledgments: The authors gratefully acknowledge APFNet Scholarship funding the first author's research at Beijing Forestry University.

Conflicts of Interest: The authors declare no conflict of interest.

\section{References}

1. TIES. The International Ecotourism Society. Available online: https://ecotourism.org/ (accessed on 17 April 2019).

2. Das, M.; Chatterjee, B. Ecotourism: A panacea or a predicament? Tour. Manag. Perspect. 2015, 14, 3-16. [CrossRef]

3. Manu, I.; Kuuder, C.-J.W. Community-Based Ecotourism and livelihood Enhancement in Sirigu, Ghana. Int. J. Humanit. Soc. Sci. 2012, 2, 97-108.

4. Tisdell, C. Economic Aspects of Ecotourism: Wildlife-based Tourism and Its Contribution to Nature. Sri Lankan J. Agric. Econ. 2003, 05, 1-14. [CrossRef]

5. Bith, B. Community-Based Ecotourism and Empowerment of Indigenous People: The Case of Yeak Laom Community Development, Cambodia; Lincoln University: Lincoln, UK, 2011.

6. Reimer, J.K.; Walter, P. How do you know it when you see it? Community-based ecotourism in the Cardamom Mountains of southwestern Cambodia. Tour. Manag. 2013, 34, 122-132. [CrossRef]

7. Prummel, R.H. An Anthropological View on Human Capacity Building for Community-Based Ecotourism in Cambodia; Vrije Universiteit Amsterdam: Amsterdam, The Netherlands, 2010.

8. CCBEN. Baseline Study on CBET in Cambodia; Cambodia Community Based Ecotourism Network and Netherlands Development Organization: Phnom Penh, 2008.

9. Lonn, P.; Mizoue, N.; Ota, T.; Kajisa, T.; Yoshida, S. Evaluating the Contribution of Community-based Ecotourism (CBET) to Household Income and Livelihood Changes: A Case Study of the Chambok CBET Program in Cambodia. Ecol. Econ. 2018, 151, 62-69. [CrossRef] 
10. Reuy, R. Ecotourism in Cambodia up 9.7 Percent. Available online: https://www.phnompenhpost.com/ business/ecotourism-cambodia-97-cent (accessed on 21 April 2019).

11. Va, M.; Om, S.; Touch, M. Award Winner: Chambok Community-Based Ecotourism Project. 2013. Available online: http://www.to-do-contest.org/preistraeger-en/pdf/kambodschar-2014-e.pdf (accessed on 12 December 2018).

12. Men, P. Tourism, Poverty, and Income Distribution: Chambok Community-Based Ecotourism Development, Kirirom National Park, Kompong Speu Province; Royal Government of Cambodia: Phnom Penh, Cambodia, 2013.

13. Wunder, S. Ecotourism and economic incentives-An empirical approach. Ecol. Econ. 2000, 32, 465-479. [CrossRef]

14. Nyaupane, G.P.; Poudel, S. Linkages among biodiversity, livelihood, and tourism. Ann. Tour. Res. 2011, 38, 1344-1366. [CrossRef]

15. Rainforest Alliance. Buenas Prácticas Para Turismo Sostenible; Rainforest Alliance: New York, NY, USA, 2008.

16. Drumm, A. The Threshold of Sustainability for Protected Areas. Bioscience 2008, 58, 782-783. [CrossRef]

17. Butcher, J. Tourism and poverty reduction: Pathways to prosperity. J. Policy Res. Tour. Leis. Events 2011, 3, 99-101. [CrossRef]

18. Mitchell, J.; Ashley, C. Tourism and Poverty Reduction; Earthscan: London, UK, 2010.

19. Chheang, V. The Political Economy of Tourism in Cambodia. Asia Pac. J. Tour. Res. 2008, 13, 281-297. [CrossRef]

20. Tosun, C. Limits to community participation in the tourism development process in developing countries. Tour. Manag. 2000, 21, 613-633. [CrossRef]

21. Scheyvens, R. Ecotourism and the empowerment of local communities. Tour. Manag. 1999, 20, 245-249. [CrossRef]

22. Peake, S.; Innes, P.; Dyer, P. Ecotourism and conservation: Factors influencing effective conservation messages. J. Sustain. Tour. 2009, 17, 107-127. [CrossRef]

23. Stem, C.J.; Lassoie, J.P.; Lee, D.R.; Deshler, D.D.; Schelhas, J.W. Community Participation in Ecotourism Benefits: The Link to Conservation Practices and Perspectives. Soc. Nat. Resour. 2003, 16, 387-413. [CrossRef]

24. Okazaki, E. A Community-Based Tourism Model: Its Conception and Use. J. Sustain. Tour. 2008, 16, 511-529. [CrossRef]

25. Salazar, N.B. Community-based cultural tourism: Issues, threats and opportunities. J. Sustain. Tour. 2012, 20, 9-22. [CrossRef]

26. Guha, I.; Ghosh, S. Does Tourism Contribute to Local Livelihoods? A Case Study of Tourism, Poverty and Conservation in the Indian Sundarbans. Work. Pap. South Asian Netw. Dev. Environ. Econ. 2007, 9, 1-53.

27. Turpie, J.; Branes, J.; Arntzen, J.; Nherera, B.; Lange, G.-M.; Buzwani, B. Economic Value of the Okavango Delta, Botswana, and Implications for Management. 2006. Available online: http://www.anchorenvironmental.co. za/Documents/Pdfs/OkawangoDeltaValuationFINALREPROT2006.pdf (accessed on 16 October 2018).

28. Mopelwa, G.; Blignaut, J. The Okavango delta: The value of tourism. S. Afr. J. Econ. Manag. Sci. 2014, 9, 113-127. [CrossRef]

29. Liu, C.; Xiao, W.; Li, J.; Pechacek, P. Attitude of tourists visiting nature reserves in China. Tour. Manag. Perspect. 2013, 5, 1-4. [CrossRef]

30. Hein, L. Economic Benefits Generated by Protected Areas: The Case of the Hoge Veluwe Forest, the Netherlands. Ecol. Soc. 2011, 16, 1-19. [CrossRef]

31. Scheyvens, R. Exploring the Tourism-Poverty Nexus. Curr. Issues Tour. 2007, 10, 231-254. [CrossRef]

32. Bowler, D.E.; Buyung-Ali, L.M.; Healey, J.R.; Jones, J.P.; Knight, T.M.; Pullin, A.S. Does community forest management provide global environmental benefits and improve local welfare? Front. Ecol. Environ. 2012, 10, 29-36. [CrossRef]

33. Ferraro, P.J.; Hanauer, M.M. Through what mechanisms do protected areas affect environmental and social outcomes? Philos. Trans. R. Soc. B Biol. Sci. 2015, 370, 20140267. [CrossRef]

34. Pohjola, I.; Puusa, A. Group dynamics and the role of ICT in the life cycle analysis of community of practice-based product development: A case study. J. Knowl. Manag. 2016, 20, 465-483. [CrossRef]

35. Cirella, G.; Iyalomhe, F.; Jensen, A.; Akiyode, O. Exploring Community of Practice in Uganda's Public Sector: Environmental Impact Assessment Case Study. Sustainability 2018, 10, 2502. [CrossRef]

36. Nault, S.; Stapleton, P. The community participation process in ecotourism development: A case study of the community of Sogoog, Bayan-Ulgii, Mongolia. J. Sustain. Tour. 2011, 19, 695-712. [CrossRef]

37. Saufi, A.; O'Brien, D.; Wilkins, H. Inhibitors to host community participation in sustainable tourism development in developing countries. J. Sustain. Tour. 2014, 22, 801-820. [CrossRef] 
38. de los Angeles Somarriba-Chang, M.; Gunnarsdotter, Y. Local community participation in ecotourism and conservation issues in two nature reserves in Nicaragua. J. Sustain. Tour. 2012, 20, 1025-1043. [CrossRef]

39. Balodi, K.; Naithani, S.; Kaur, J.; Singh, A.; Singh, A. Eco-tourism A Sustainable Livelihood Option for Mountainous Communities in Uttarkashi, Uttarakhand, India. J. Stud. Dyn. Chang. 2014, 1, 2348-7038.

40. Sangpikul, A. Ecotourism Impacts on the Economy, Society and Environment of Thailand. J. Rev. Glob. Econ. 2017, 6, 302-312. [CrossRef]

41. Heinen, J.T.; Shrestha-Acharya, R. The Non-Timber Forest Products Sector in Nepal: Emerging Policy Issues in Plant Conservation and Utilization for Sustainable Development. J. Sustain. For. 2011, 30, 543-563. [CrossRef]

42. Das, B.K. Role of NTFPs Among Forest Villagers in a Protected Area of West Bengal. J. Hum. Ecol. 2005, 18, 129-136. [CrossRef]

43. Brockington, D.; Wilkie, D. Protected areas and poverty. Philos. Trans. R. Soc. B Biol. Sci. 2015, 370, 20140271. [CrossRef]

44. Ma, B.; Cai, Z.; Zheng, J.; Wen, Y. Conservation, ecotourism, poverty, and income inequality-A case study of nature reserves in Qinling, China. World Dev. 2019, 115, 236-244. [CrossRef]

45. Ven, S. Host Residents' Attitude toward Community-based Ecotourism: Empirical Study in Southwestern Cambodia. J. Tour. Hosp. 2015, 04, 1-11.

46. Walter, P. Local knowledge and adult learning in environmental adult education: Community-based ecotourism in southern Thailand. Int. J. Lifelong Educ. 2009, 28, 513-532. [CrossRef]

47. Dowie, M. Conservation Refugees: The Hundred-Year Conflict between Global Conservation and Native Peoples; MIT Press: Cambridge, MA, USA, 2011; ISBN 0262516004.

48. Kimengsi, J.; Pretzsch, J.; Kechia, M.; Ongolo, S. Measuring Livelihood Diversification and Forest Conservation Choices: Insights from Rural Cameroon. Forests 2019, 10, 81. [CrossRef]

49. Thapa, B.; Parent, G. Tourists' willingness to accept/pay increased entry fees for park improvement projects. Curr. Issues Tour. 2018, 23, 1-5. [CrossRef]

50. Tourism Cambodia Mondulkiri Province Travel Guides, Cambodia. Available online: https://www. tourismcambodia.com/travelguides/provinces/mondulkiri.htm (accessed on 26 August 2019).

51. Ou, R.; Mitsuyasu, Y. Analyzing decision-making by tourist for ecotourism Using Latent Segment Model in Phnom Prich Wildlife Sanctuary. In Emerging Trends, Challenges and Innovations; CBNRM Learning Institute, Ed.; Community Based Natural Resource Management: Phnom Penh, Cambodia, 2009.

52. Bousra Waterfall, M. Bousra Waterfall, Attraction in Mondulkiri, Cambodia. Available online: https://www. tourismcambodia.com/travelguides/provinces/mondulkiri/what-to-see/192_bou-sra-waterfall.htm (accessed on 26 August 2019).

53. Yamane, T. Statistics: An Introductory Analysis, 2nd ed.; Harper and Row: New York, NY, USA, 1967.

54. McFadden, D.L. Frontiers in Econometrics; Wiley: New York, NY, USA, 1973.

55. PDoT. Annual Report; Provincial Department of Tourism: Senmonorom, Cambodia, 2018.

56. Walter, P.; Regmi, K.D.; Khanal, P.R. Host learning in community-based ecotourism in Nepal: The case of Sirubari and Ghalegaun homestays. Tour. Manag. Perspect. 2018, 26, 49-58. [CrossRef]

57. Straka, T.M.; Bal, P.; Corrigan, C.; Di Fonzo, M.M.I.; Butt, N. Conservation leadership must account for cultural differences. J. Nat. Conserv. 2018, 43, 111-116. [CrossRef]

58. Gui, Y.; Fang, Y.; Liu, J. Community-based ecotourism in nature reserve of China. Chin. Geogr. Sci. 2004, 14, 276-282. [CrossRef]

59. Poe, M.R.; McLain, R.J.; Emery, M.; Hurley, P.T. Urban Forest Justice and the Rights to Wild Foods, Medicines, and Materials in the City. Hum. Ecol. 2013, 41, 409-422. [CrossRef]

60. Marshall, E.; Schreckenberg, K.; Newton, A.C. Commercialization of Non-Timber Forest Products: Factors Influencing Success. Lessons Learned from Mexico and Bolivia and Policy Implications for Decision-Makers; UNEP World Conservation Monitoring Centre: Cambridge, UK, 2006.

61. Liu, J.; Ouyang, Z.; Miao, H. Environmental attitudes of stakeholders and their perceptions regarding protected area-community conflicts: A case study in China. J. Environ. Manage. 2010, 91, 2254-2262. [CrossRef]

(C) 2019 by the authors. Licensee MDPI, Basel, Switzerland. This article is an open access article distributed under the terms and conditions of the Creative Commons Attribution (CC BY) license (http://creativecommons.org/licenses/by/4.0/). 